\title{
Assessing the Socioeconomic Impacts of the Informal Sector in Guinea, West Africa
}

\author{
Aissata Diallo" ${ }^{*}$, Zhonghua Yin ${ }^{1}$, Mukete Beckline ${ }^{2}$ \\ ${ }^{1}$ School of Economics and Management, Beijing Forestry University, Beijing, China \\ ${ }^{2}$ School of Forestry, Beijing Forestry University, Beijing, China \\ Email: *aicha2diallo@gmail.com, yinzhonghua@bjfu.edu.cn, munasawa@gmail.com
}

How to cite this paper: Diallo, A., Yin, Z.H. and Beckline, M. (2017) Assessing the Socioeconomic Impacts of the Informal Sector in Guinea, West Africa. Open Access Library Journal, 4: e3290.

http://dx.doi.org/10.4236/oalib.1103290

Received: December 9, 2016

Accepted: January 13, 2017

Published: January 16, 2017

Copyright $(\odot) 2017$ by authors and Open Access Library Inc.

This work is licensed under the Creative Commons Attribution International License (CC BY 4.0).

http://creativecommons.org/licenses/by/4.0/

(c) (i) Open Access

\begin{abstract}
This paper examines the characteristics and socioeconomic importance of the informal sector in Africa with particular emphasis on Guinea Republic. Specifically, it aims at identifying the main economic activities and how these create a positive financial force for local development. To attain this goal, we carried out a comprehensive review of published literature obtained through Research gate, Web of science, Google scholar and Mendeley. It was observed that though the informal sector drags behind developmental processes, it subsidizes unemployment for many urban poor and rural communities. The sector is also very prominent and constitutes a major source of financial returns for the state through taxes. The contribution to the developmental process through this sector can be achieved if appropriate management strategies are adequately implemented. This will also boost and increase government's level of tax collections and enhance poverty alleviation in poor urban and rural communities.
\end{abstract}

\section{Subject Areas}

Development Economics, Environmental Economics

\section{Keywords}

Guinea, Informal Sector, Local Development, Poverty Alleviation, Socioeconomic Development

\section{Introduction}

In South Asia, sub-Saharan Africa, Latin America and Small Island States (emerging economies), the rise in income inequality during the past three decades has been unprecedented [1] [2]. This relationship appears to be particularly strong in countries where a large part of the population lives in a poverty trap. 
This poverty trap globally includes over 836 million people with one in five people in developing regions still living on less than $\$ 1.25$ a day [3]. The overwhelming majority of these people are in South Asia, sub-Saharan Africa, Latin America and Small Island States [4] [5]. The manifestations of poverty include hunger and malnutrition, limited access to education and other basic services, social discrimination and exclusion as well as the lack of participation in decision-making. Economic growth must be inclusive to provide sustainable jobs and promote equality [4] [6].

In African countries, this poverty trap has seen the rise of a new sector known as the informal sector. The informal sector refers to privately owned small- and medium-scale enterprises that are officially registered to undertake business activities [7]. It has become so prominent especially because the socioeconomic development depends on the mobilization of resources at both national and local level. Though not being a specific context, the socioeconomic importance of this sector in Africa gives it a unique character [8]. In these African countries, the informal sector has an overwhelming importance for its response to poverty and unemployment and where informal entrepreneurs drive job creation through small-businesses [9]. From another perspective, the sector is considered to be an incubator for business potentials and a stepping stone for accessibility and graduation to the formal economy. Studies by [10] observed that the sector absorbs the majority of the workforce which makes about $60 \%-90 \%$ of the overall employment. This often results in a fall in capital per person and a negative growth rate of per capita income with a further impoverishment of the household in the future.

In sub-Saharan Africa the informal sector includes a wide and diverse range of professions working in diverse economic activities (trade, crafts, services, agriculture, and livestock). Several studies [10] [11] have looked at the role and size of the informal sector in developing countries. They observed tax enforcement capacity of a country to be the major determinant of a country's informality. Relatedly, [8] found firms operating in the informal sector to be less regulated and less taxed than firms in the formal sector. This allows them to operate more efficiently and create a positive financial force for development. Elsewhere, other studies [12] observed distortions might arise in the presence of a large informal sector because informality is closely associated with lack of tax law enforcement.

In recent years, many African countries have experienced a growth revival, but this has not necessarily generated decent jobs hence unemployment still remains high especially among youths. Many African governments pay little attention to the role of the informal sector in fostering growth and job creation.

Our study seeks to add to the existing knowledge by examining the socioeconomic importance of the informal sector in Africa particularly in the Republic of Guinea. This will help create the possibility of building a broad knowledge on the informal sector levels of development and related socioeconomic dimensions in Guinea. It could further provide a basis for the sustainable management, adequate planning, poverty alleviation, and economic growth of the sector elsewhere in Africa. 
The study is divided into two sections with the first looking at the characteristics and socioeconomic importance of the informal sector in Africa. In the second section, we identify the main economic activities and how these create a positive financial force for local development in the Republic of Guinea.

\section{Characteristics of the Informal Sector in Africa}

In Africa, this sector was first described in 1970s and in 1990s the International Labour Organization (ILO) expanded the description to include private unincorporated enterprises. These enterprises produced at least some of their goods and services for sale or barter, had less than 5 paid employees, are not registered, engaged in non-agricultural, professional and technical services [10]. Therefore, the informal sector may be broadly characterized as consisting of units engaged in the production of goods or services with the primary objective of generating employment and income to the persons concerned [8]. These characteristics encompass the legal status, type of employment, and additional enterprise based criteria. For instance, from the legal perspective, the household enterprise would not be independent of its owner, and would not have a complete set of accounts. According to [13], the informal economy comprises of activities, which are carried out at home or in an enterprise by solely the owner or by the owner and a limited number of employees. It stems from this description that the informal sector must be market oriented, have size and be registered. In market orientation (production), all or at least some of the goods or services produced should be meant for sale and bartered. This excludes production solely destined for household consumption or personal use. Additionally, the size and/or registration of employment should be under a determined threshold. Here there should be non-registration of the units, employees under factories or commercial acts, tax or social security laws, professional groups, regulatory acts, or similar acts, laws or regulations established by national legislative bodies [14].

According to [15] [16], the informal sector consists of all activities operating outside the official legal and fiscal system, with a resulting lack of reliable statistical information. Here, the sector is very heterogeneous with both subsistence activities and lucrative segments giving it a dual dimension [17]. Though this encompasses considerable diversity and complexity of the informal sector in Africa, many firms are micro-enterprises. Some enterprises straddle the formal and informal sectors, and the distinction between formal and informal status can be viewed as a continuum rather than a sharp division.

The informal sector contributes about 55\% of Sub-Saharan Africa's Gross Domestic Product (GDP) and $80 \%$ of the labour force [18]. Also about $90 \%$ of rural and urban workers have informal jobs in Africa with a majority of these employees being women and youths. This prominence of the informal sector in most African economies stems from the opportunities it offers to the most vulnerable populations such as the poorest, women and youth. Even though the informal sector is an opportunity for generating reasonable incomes for many people, most informal workers are without secure income, employments benefits 
and social protection. Therefore, informality often overlaps with poverty where decreasing informality decreases the number of working poor [19] [20]. Also, informality is thought to distort the natural competitive process as informal firms enjoy an unfair cost advantage through tax avoidance. According to [20] some informal firms reduce their scale of operation in order to remain undetected by the government, which makes them less efficient. Similarly, [21] posited that informality is a drag on the development process because it subsidizes employment in less productive activities.

This informal economy is often associated with increasing poverty and weak employment conditions and where, middle-income countries have smaller informal sectors but higher unemployment rates than the poorest countries. Therefore, by investing through informal channels, African entrepreneurs strive to reduce costs related to wages, retirement pensions and other social benefits [22] [23]. This goes beyond poverty and social issues and it is closely related to an environment characterized by weaknesses in three core institutional domains such as taxation, regulation and private property rights. Higher taxes and complicated fiscal process often prevent informal sector operators from formalizing their activities. This is further exacerbated by long requirements for registration as well as licensing and inspection requirements thus stifling the informal sector [18] [19]. In addition, investors in the informal sector in Africa have limited access to capital, lack proper skills, adequate education and training which therefore impedes the sector in Africa. Furthermore, the limited access to technology, poor infrastructure, and failure by governments to include this sector on the development agenda, all hinder the proper functioning of this sector.

That notwithstanding, the informal sector plays an important role as it facilitates the successful adjustment to globalization and structural reforms. It is also thought to be a survival mechanism for a vast majority of rural and urban poor as well as a means to unlock individual entrepreneurial skills [24].

Several studies [25] and [26] have observed a positive correlation between the informal sector and poverty. Also, [27] found evidence that the average income earned in the informal sector is lower than that earned in the formal sector. This is because, the informal sector is characterized by several units engaged in the production of goods or services whose primary goals is employment and income generation for those directly involved.

The informal sector represents the dominant share of many sectors across the continent, especially in manufacturing, commerce, finance and mining. Traderelated activities such as street vending, is the most common form of activity in Africa's informal sector. This informal sector provides between $50 \%-75 \%$ of employment and $72 \%$ of non-agricultural employment with the exclusion of about 78\% of the South Africa population [10] [28] [29]. According to [26] [29], the sector made up about $42 \%$ of Gross National Income (GNI) in 2000 which ranged from $30 \%$ in South Africa to $60 \%$ in Tanzania and Nigeria. Similarly, [24] found about $93 \%$ of new jobs created in sub-Saharan Africa during the 19 were in the informal sector. Meanwhile [28] and [30] observed that informal 
sector employment in Uganda and Kenya now exceeds employment in the formal sector whereas over $90 \%$ of the labour force in Ghana and Mali comes from the informal sector (see Table 1).

The informal economy is considered as the real driving force behind the Angolan economy and it offered a large majority of poor families during the post conflict period essential outlets for their local products, such as fish, and agricultural products. An analysis of income and expenditure in Angola further revealed that, $72 \%$ of households have at least one member working in the informal economy (including $78 \%$ in Luanda, the capital), and that there are twice as many women as men in this type of activity. The self-employed accounts for over $82 \%$ of the sector's workers compared to $18 \%$ for micro small enterprises owner/managers. Most of the women worked in food processing, clothe-making, and trading sectors in order to meet the basic needs of their families [28].

According to [18], middle-income countries have smaller informal sectors but higher unemployment rates than the poorest countries. By investing through informal channels, African entrepreneurs seek to reduce costs related to wages, retirement pensions and other social benefits [18]. These informal workers are not protected by law and are exposed to numerous forms of abuse as well as exploitation. Studies by [25] showed that expansions of the informal sector in urban settings potentially exacerbate problems connected with slums, congestion, health, and environment.

\section{Socioeconomic Impact of the Informal Sector in Guinea}

The origins of the informal sector in Guinea are unknown but it is important to clarify that the sector has taken advantage of the socioeconomic context and policy. This contextual political framework has prevailed for almost half a century during successive socialist regimes of the post-independence era. It is estimated that at least two-thirds of the economically active population are employed in the informal sector [31] [32]. The main features of the sector's activities in Guinea as elsewhere in Africa are small in size with the absence of a nonpermanent salary and the lack of access to bank credit.

Table 1. Informal Sector as a Job Provider across Africa. Source: According to World Bank data, WAEMU 1-2-3 Surveys, 2001-2003. Walther, R (2007).

\begin{tabular}{cccc}
\hline Country & $\begin{array}{c}\text { Proportion of Informal } \\
\text { Sector employment }\end{array}$ & $\begin{array}{c}\text { Proportion of employment } \\
\text { in companies }\end{array}$ & $\begin{array}{c}\text { Proportion of employment } \\
\text { in administration }\end{array}$ \\
\hline South Africa & $31 \%$ (all sector) & $69 \%$ & - \\
Angola & $66 \%$ (urban sector) & $24 \%$ & $10 \%$ \\
Benin & $95 \%$ & $5 \%$ & $4.9 \%$ \\
Cameroon & $90.4 \%$ (all sectors) & $4.7 \%$ & $2.6 \%$ \\
Ethiopia & $90 \%$ (all sectors) & $6.2 \%$ & $5.7 \%$ \\
$\begin{array}{l}\text { Senegal } \\
\text { (Dakar) }\end{array}$ & $77.5 \%$ (urban sector) & & \\
\hline
\end{tabular}


In Guinea, the informal sector has four main characteristics which include a significant weight on the economy, a presence in the modern (formal) sector, a link with the public sector, and an internal dynamism in a difficult economic environment. Hence, with the absence of a non-permanent salary, lack of access to credit and formal wage labour market, the informal sector provides practical employment solutions. The real challenge to the government in Guinea is to provide employment for the majority of its citizens particularly the poor, who have very limited kills to operate in the formal wage labour market. In this respect, the informal sector potentially holds a key to the solution of this problem. This is especially important in the context of prevailing public sector retrenchment imposed by the necessities of policy reforms and structural adjustment programs.

The Guinean economy has large informal sectors and where over $20 \%$ of informal self-employed persons receive very high incomes than formal sector workers. About $96 \%$ of Guinea's workforce is employed in the informal sector such as agriculture, livestock, fishing, handicrafts, trade, and local industry. Poor households are therefore able to derive a higher share of their revenue from independent micro-enterprises, located in the informal sector than from other activities [33] [34]. This shows that informal sector development has direct implications for poverty alleviation in Guinea (Table 2).

\subsection{Constraints to Informal Sector Development in Guinea}

There are both individual and environmental constraints to informal sector development in Guinea. People operating in the informal sector, regardless of gender, are limited by their lower level of education as compared to the general population, particularly those operating in the formal sector. At the environmental level, such development is constrained by poor infrastructure in transportation and communication. This, in turn, restricts the expansion of enterprises that may prove locally profitable. Furthermore, as a result of a limited access to formal financial services, these enterprises cannot borrow for medium to long-term projects.

Similarly, small enterprises in the form of small industries which are more capital-intensive and headed by men also constitute part of the informal sector in Guinea. Therefore, women may be facing some discrimination in the credit market. Such discriminations in combination with the low level of education

Table 2. Annual recovery rate in Guinea informal sector from 2008 to 2010 in the local currency Guinea Franc (GNF) where 1 US\$ equals 9200 GNF. Source: Aissata Diallo field studies personal communication Kissidougou District of Guinea, 2011.

\begin{tabular}{cccccc}
\hline \multirow{2}{*}{ Number } & $\begin{array}{c}\text { Fiscal } \\
\text { years }\end{array}$ & $\begin{array}{c}\text { Number of } \\
\text { taxpayers }\end{array}$ & $\begin{array}{c}\text { Emissions } \\
\text { (GNF) }\end{array}$ & $\begin{array}{c}\text { Recoveries } \\
\text { (GNF) }\end{array}$ & $\begin{array}{c}\text { Recovery rate } \\
\text { (\%) }\end{array}$ \\
\hline 1 & 2008 & 440 & $85,250,000$ & $41,249,200$ & 48.38 \\
2 & 2009 & 305 & $61,520,000$ & $40,991,000$ & 66.63 \\
3 & 2010 & 150 & $43,800,000$ & $33,850,000$ & 77.28 \\
& \multirow{2}{*}{ Total } & - & $190,570,000$ & $116,090,200$ & 60.91 \\
\hline
\end{tabular}


make it hard for womenfolk in Guinea to start-off small businesses in the noncommercial sector [33] [34].

\subsection{Sustaining the Informal Sector Development in Guinea}

Given the important role that the informal sector plays in providing livelihoods for the poorer segments of the population, it is crucial that any poverty alleviation strategy address these constraints to the sector's development. In particular, consideration must be given to the establishment of a proper regulatory framework that encourages the development of this sector. As Guinea strives to maintain a profitable informal sector for the state and business owners, the identified sources of constraints must be improved and adequately overhauled. Hence, identifying the sources of constraints and factors that affect it may provide useful information for the formulation of economic policies likely to improve on the socioeconomic roles of the informal sector. More so, identifying the factors that may improve profitability to both the state and enterprise owners is of major significance because by using information derived from such studies, smallscale businesses may become more sustainable and productive.

Bringing forth several good questions that can be answered is difficult due to the absence of scientific literatures about the study area. Areas for further research could examine how the informal sector contributes to the impoverishment of the state by the non-payment of taxes and disinvestment in the modern sector because of the unfair competition from informal firms. Similarly, field work could be used to evaluate the informal sector and how its quantitative aspects in employment, income distribution, value creation and production of accessible goods and services mainstream the Guinean economy.

\section{Conclusion}

In this study, we tried to examine the characteristics and socioeconomic importance of the informal sector in Africa with particular emphasis on Guinea Republic. We observed that the informal sector offers significant opportunities for poverty alleviation and sustainable development if the necessary infrastructure and support are provided and facilitated. The individual and environmental constraints to the informal sector development in Guinea are a continuous process requiring constant monitoring and evaluation. The role of socioeconomic causes such as lack of access to credit, lower level of education as compared to those in the formal sector and government policies require more attention. At the environmental level, development is constrained by poor infrastructure in transportation and communication which restricts the expansion of enterprises that may prove locally profitable. Thus understanding their functioning and state will help define, develop and implement adequate government policies.

\section{References}

[1] Krueger, D., Perri, F., Pistaferri, L. and Violante, G. (2010) Cross Sectional Facts for 
Macroeconomists. Review of Economic Dynamics, 13, 1-26. https://doi.org/10.1016/j.red.2009.12.001

[2] IMF (2016) International Monetary Fund. World Economic Outlook: Globalization and Inequality, International Monetary Fund, Washington DC.

https://blog-imfdirect.imf.org/2016/03/17/globalization-skills-inequality/

[3] Phimmachanh, S., Zhang, Y. and Mukete, B. (2015) Bamboo Resources Utilization: A Potential Source of Income to Support Rural Livelihoods. Applied Ecology and Environmental Sciences, 3, 176-183.

[4] Ravallion, M., Chen, S. and Sangraula, P. (2013) Dollar a Day Revisited. The World Bank Economic Review, 23, 163-184. https://doi.org/10.1093/wber/lhp007

[5] Vongkhamheng, C., Zhou, J., Mukete, B. and Phimmachanh, S. (2016) Socioeconomic and Ecological Impact Analysis of Rubber Cultivation in Southeast Asia. Open Access Library Journal, 3, e2339. https://doi.org/10.4236/oalib.1102339

[6] UNDP (2015) Eradicate Extreme Poverty and Hunger. Where Do We Stand?

[7] Olofin, S. and Folawewo, A. (2006) Skill Requirements, Earnings and Labour Demand in Nigeria's Urban Informal Sector. In: Guha-Khasnobis, B. and Kanbur, R., Eds., Informal Labour Markets and Development, Palgrave Macmillan, Geneva, 180-195.

[8] Schneider, F. and Klinglmair, R. (2004) Shadow Economies around the World: What Do We Know? IZA Discussion Paper No. 1043; CESifo Working Paper Series No. 1167. https://ssrn.com/abstract=518526

[9] Kuchta-Helbling, C. (2012) Tapping Hidden Fortunes. Center for International Private Enterprise. http://cipe.org/publications/detail/tapping-hidden-fortunes

[10] ILO (2012) International Labour Organization. Statistical Update on Employment in the Informal Economy ILO, Department of Statistics.

http://laborsta.ilo.org/applv8/data/INFORMAL_ECONOMY/2012-06-Statistical\%2 Oupdate\%20-\%20v2.pdf

[11] Perry, G., Arias, H., Maloney, W. and Servén, L. (2006) Poverty Reduction and Growth: Virtuous and Vicious Circles. World Bank, Washington DC. https://doi.org/10.1596/978-0-8213-6511-3

[12] Loayza, N. and Rigolini, J. (2006) Informality Trends and Cycles. Policy Research Working Paper 4078, World Bank, Washington DC.

[13] AFD (Agency Française de Development) (2007) The Ubiquitous Nature of the Informal Sector in Developing Countries.

http://www.afd.fr/jahia/webdav/site/afd/shared/PUBLICATIONS/RECHERCHE/Ar chives/Notes-et-documents/33-notes-documents-VA.pdf

[14] Maloney, W. (2004) Informality Revisited. World Development, 32, 1159-1178. https://doi.org/10.1016/j.worlddev.2004.01.008

[15] Benjamin, N. and Mbaye, A. (2012) Informality, Productivity, and Enforcement in West Africa: A Firm-Level Analysis. Review of Development Economics, 16, 664680. https://doi.org/10.1111/rode. 12010

[16] Henley, A., Reza, A. and Francisco, G. (2006) On Defining and Measuring the Informal Sector. IZA Discussion Papers 2473, Institute for the Study of Labor (IZA) and World Bank Policy Research Working Paper 3866.

[17] Blunch, H., Canagarajah, S. and Raju, D. (2001) The Informal Sector Revisited: A Synthesis across Space and Time. Social Protection Discussion Paper Series, No. 0119, World Bank, Washington DC.

[18] ADB (African Development Bank) (2013) Recognizing Africa’s Informal Sector. 
http://www.afdb.org/en/blogs/afdb-championing-inclusive-growth-across-africa/po st/recognizing-africas-informal-sector-11645/

[19] Atias, R. (2013) A Focus on Africa's Informal Economy. http://www.huffingtonpost.com/richard-attias/africa-informal-economy_b_300155 2.html

[20] Farrell, D. (2006) Tracking the Informal Economy. Business Week. http://www.mckinsey.com/aboutus/mckinseynews/tacklingeconomy.asp

[21] Levy, S. (2008) Good Intentions, Bad Outcomes: Social Policy, Informality, and Economic Growth in Mexico. Brookings Institution Press, Washington DC.

[22] Farrell, D. (2004) The Hidden Dangers of the Informal Economy. McKinsey Quarterly, 3, 27-37.

[23] Ahmadou, M. (2015) The Importance of the Informal Sector in West Africa. https://www.weforum.org/agenda/2015/03/the-importance-of-the-informal-sector-i n-west-africa/

[24] Guha-Khasnobis, B., Ravi, K. and Elinor, O. (Eds.) (2006) Linking the Formal and Informal Economy: Concepts and Policies. Oxford University Press, Oxford.

[25] Chen, M. (2001) Women in the Informal Sector: A Global Picture, the Global Movement. SAIS Review, 21, 71-82. https://doi.org/10.1353/sais.2001.0007

[26] Katungi, E. (2006) Social Capital and Technology Adoption: The Case of Banana Production Technology in Uganda. PhD Dissertation, University of Pretoria, Pretoria.

[27] Paillaud, O., Rakotomanana, F. and Roubaud, F. (1998) Taxation of the Sector Informal: Is the Deposit Available and Can It Be Exploited? Madagascar, 3, 185-214.

[28] AU (African Union) (2008) Study on the Informal Sector in Africa. 6th Ordinary Session of the Labor and Social Affairs Commission of the African Union, Document No. LSC/EXP/4(VI), Addis Ababa, 21-25 April 2008.

[29] Verick, S. (2008) The Impact of Globalization on the Informal Sector in Africa. Economic and Social Policy Division, UNECA, Addis Ababa.

[30] Devey, R., Skinner, C. and Valodia, I. (2006) Second Best? Trends and Linkages in the Informal Economy in South Africa. School of Development Studies, University of KwaZuluNatal, Working Paper 06/102. Durban.

[31] Walker, A. (1995) Informal Sector in Guinea. In: Webster, L. and Fidler, P., Eds., Informal Sector and Microfinance Institutions in Western Africa, World Bank, Washington DC.

[32] Gerard, C. (2009) L'Afrique au Sud du Sahara: Mobiliser les resources fiscales pour le développement, édition, Economica. Guide du Régime fiscal de la Guinée Française de 1955, 382 p.

[33] CIA (206) Central Intelligence Agency. World Fact Book. https://www.cia.gov/library/publications/the-world-factbook/geos/gv.html

[34] Losby, J. and Edgcomb, L. (2002) Informal Economy Literature Review. Working Paper, USA ISED Consulting and Research and the Aspen Institute. 
Submit or recommend next manuscript to OALib Journal and we will provide best service for you:

- Publication frequency: Monthly

- 9 subject areas of science, technology and medicine

- Fair and rigorous peer-review system

- Fast publication process

- Article promotion in various social networking sites (LinkedIn, Facebook, Twitter, etc.)

- Maximum dissemination of your research work

Submit Your Paper Online: Click Here to Submit

Or Contact service@oalib.com 